\title{
Accounting Conservatism and Disposition Effect
}

\author{
Ying Zhao \\ Economy and Management School, Beihang University \\ Beijing, China \\ E-mail: zhaoying801@buaa.edu.cn \\ Roger $\mathrm{Su}$ \\ Faculty of Business and Law \\ Auckland University of Technology, New Zealand \\ E-mail: Roger.su@aut.ac.nz \\ Keith Hooper \\ Faculty of Business and Law \\ Auckland University of Technology, New Zealand \\ E-mail: Keith.hooper@aut.ac.nz
}

Received: April 27, 2011 Accepted: May 20, $2011 \quad$ Published: October 1, 2011

doi:10.5539/ijbm.v6n10p94 URL: http://dx.doi.org/10.5539/ijbm.v6n10p94

\begin{abstract}
The current financial crisis which began in 2008 created economic disruption on a global level. This study investigates the effect of accounting conservatism on the disposition effect in the Chinese capital markets. Our research findings show accounting conservatism offsets "overestimation "and "underestimation" resulting from the disposition effect. From an accounting perspective, we find the governance role of conservatism may correct inaccurate market pricings; we believe this research provides knowledge that will assist investors and policy makers to understand accounting conservatism and make better decisions.
\end{abstract}

Keywords: Disposition effect, Accounting conservatism, Asset pricing, Accounting governance

\section{Introduction}

The full-blown sub-prime crisis that occurred in 2008 caused a worldwide stock market upheaval. Academic and professionals began to revalue the qualitative information provided by accounting conservatism deeply and believe accounting standard-setting agencies and financial regulators should work together and add counter-cyclical factors to the current financial regulatory system, and design a timely and effective "Circuit Breaker "mechanism to correct the financial markets and financial institutions' pro-cyclical behavior. There are a number of factors concerned in perspective of accounting reform, such as, for example, the affect of capital market fluctuations and determining which kinds of accounting information to use. This research will investigate the effect of accounting conservatism on the disposition effect- one irrational pricing behavior in market, and try to provide valuable information for investors and policy makers.

\section{Theory Assumptions}

The disposition effect was put forward by Shefrin and Statman (1985) according to prospect theory and mental account, that is, investors tend to hold losing stocks too long and sell profitable stocks too quickly. In other words, prospect theory predicts that the decline in utility from realizing losses relative gains leads investors to hold losers and sell winners even if the hoped for gain from losers is not expected to be as much as from the winners. Odean (1998) supports this theory, finding that individual stock market investors are more likely to sell nominal winners than losers. Prospect theory is even more surprising when consideration of a capital gains tax associated with selling winners and possible tax benefits from realizing losses is taken into account. With regard 
to the housing market in Boston, Genesove and Mayer (2001) that in a downturn when asking prices are well above selling prices many sellers withdraw their properties without sale. Thus the support for nominal loss aversion is quite strong.

Prospect Theory (PT) and mental accounting (MA) together constitute the connotations of the disposition effect. Whereas some investors are risk averse, others prefer risk. The study showed this preference for or aversion to risk showed up in investors' different attitudes toward different levels of risk actually led to some investors who were more willing to sell winners and hold losers.

In recent years, studies have shown that the disposition effect exists not only in the United States (Thaler, 1980), Poland (Kahneman and Tversky, 1979), Finnish (Kaustia, 2004) it also exists in and other western countries, such as South Korea and other Asian countries (Szyszka and Zielonka, 2007). And the disposition effect exists not only in the stock market, but also in employee stock options (Chen, Kim, Nofsinger et al. 2007), the real estate market (Hyuk and Yunsung, 2009) as well as stock index futures market (Heath, Huddart and Lang, 1999). Barberis, Huang and Santos (2001) indicate that in the market prevailing investors subject to the prospect theory, the stock has a higher average rate of return and volatility, which indicates that the non-rational behavior will cause market volatilities and stock price bubbles. Many studies suggest that as an irrational investor behavior, the disposition effect is an important vision to explain the capital market's anomalies. Grinblatt and Han (2005) combined the disposition effect with the price momentum for the first time, and found investors' capital gain is more predictive to future stock returns than past stock returns. The disposition effect is also found from Chinese investors' behaviors (Zhao and Wang, 2001; Lu and Li 2002; Sun and Shi 2002; Li and Zhang 2005; Gao, He and Su 2005; Sun, Chen and Wang 2007, and Wang 2007).

Basu (1997) defined conservatism as "It is more stringent verifiability for accounting staff to confirm the good news than bad news". Thus, earnings reflect "bad news" more quickly than "good news". "Good news" refers to economic benefits that are positive, while "bad news" refers to economic benefits that are negative. The uncertainty that the business environment undergoes causes the unpredictability of enterprises' economic activities, therefore, accountants have to estimate and value these commercial activities. The principle of conservatism revolves around the fact that there are two or more accounting processes to choose from, and each accounting process is correct theoretically and logically. Generally, the principle requires accountants to choose the accounting process which avoid overestimating asset and gain and underestimates debt and loss, and supplies more evidence to confirm the good news (such as gain) than bad news (such as loss). Clearly, due to the asymmetry in the confirmation of "good news" and "bad news", accounting earnings' timeliness and persistence must be different during "good news" period and "bad news" period, resulting in that the adverse earning change is less persistent than the favorable earning change.

Investors' capital gain can be seen as market "news", when investors win, which equates to a capital gain greater than 0 , it can be understood as a kind of "good news", otherwise it can be understood as "bad news". When the market appears as "bad news", it will more quickly reflect in earnings, and thus will be reflected in the stock price. When facing losses, investors subject to the disposition effect are unwilling to realize gain. This behavior causes stock to be overvalued however conservatism has an offsetting effect on the overvaluation. On the other hand, when investors win, when "good news" appears, the behavior that investors hurry to realize gain will underestimate the stock price. The principle of conservatism seems not to amend the "underestimation", however because "good news" is more persistent than "bad news", as time passes and earnings gradually reflect the "good news", this affects the stock price to modify investors" non-rational behavior. Thus, we assume that conditional conservatism may have an impact on investors' disposition behavior.

\section{Research Design}

\subsection{The measure of the disposition effect}

We test the theoretical price dynamics by analyzing the relation between aggregate capital gains and the cross-section of expected returns. The method also suggests multiplying the gain by one-period lagged turnover.

The observed empirical relation between this product and the cross-section of returns is essentially the same as the results with the gain alone as the return predictor. We largely opt for the more parsimonious representation using the gain alone as the key regressor, although we report results with this product variable as the critical return predictor later in this section. The method that was applied by Grinblatt and Han (2005) which is a kind of weights calculation as follows:

$$
\mathrm{R}_{t}=\sum_{n-1}^{\infty}\left(V_{t-n} \prod_{\tau-1}^{n-1}\left[1-V_{t-n+\tau}\right]\right) P_{t-n} \text { (1) }
$$


Where $V t$ is the stock turnover at period t. Continually multiply item in parentheses is $P t-n$ 's weights, the sum of which is one, this refers to a stock that has not been traded before period $t-n$. The actual reference point calculation usually requires five years' data to calculate, so the calculation formula is as follows:

$$
\mathrm{R}_{t}=\sum_{n=1}^{60}\left(V_{t}-n \prod_{\tau=1}^{n-1}\left[1-V_{t-n+\tau}\right]\right) P_{t-n}
$$

Therefore, the formula of investors' capital gain is as follows:

$$
g_{t}=\frac{P_{t-1}-R_{t}}{P_{t-1}}
$$

Where $g t$ refers to investors' capital gain in period t; $P t-1$ refers to the closing price of the stock in period t-1; $R t$ refers to the reference point in period t. We lag the stock's closing price by one period to avoid confounding market microstructure effects, such as bid-ask bounce.

In view of the capital gain links closely to the stock return and turnover, regress $g$ with the passed stock return and turnover. According to the formula (2) (3), we can reason $g$ is negatively correlated with return and turnover, that is, coefficient $a 1-a 6$ in model (4) is significantly negative

$$
\begin{aligned}
& g=a_{0}+a_{1} r_{1}+a_{2} r_{2}+a_{3} r_{3}+a_{4} V_{1} \\
& +a_{5} V_{2}+a_{6} V_{3}+a_{7} s+\varepsilon
\end{aligned}
$$

Where, $r 1$ refers to the cumulative return that has passed one month; $r 2$ is the cumulative return from passed one month to passed one year; $r 3$ is the cumulative return from post one year to the post three years. Accordingly, $V 1$, $V 2, V 3$ is the corresponding periods'turnover; $\mathrm{s}$ is the natural logarithm of market capitalization measured at the beginning of week $\mathrm{t}$.

\subsection{The measure of accounting conservatism}

The conditional conservatism of Basu(1997) is defined as accounting earnings that react to bad news more timely relative to good news, that result in lower accounting earnings persistence. The asymmetric timeliness of the accounting earnings is defined by the following formula:

$$
X_{i t} / P_{i t-1}=\alpha_{0}+\alpha_{1} D_{i t}+\beta_{0} R_{i t}+\beta_{1} R_{i t} \times D_{i t}+\varepsilon_{i t}
$$

Where, $X$ it refers to the earnings per share of the company i in period t; $P$ it -1 refers to the stock price of the company $\mathrm{i}$ at the beginning of period $\mathrm{t} ; R$ it refers to the market return of the company $\mathrm{i}$ in period $\mathrm{t} ; D=1$ when $R$ it $<0 ; D=0$, when Rit $>0$. If conditional conservatism exists, the coefficient $\beta 1$ will be significantly greater than zero.

Lower accounting earnings persistence means that relative to good news, bad news will result in a greater degree of mean reversal of earnings changes, this definition is as follows:

$$
\begin{array}{r}
\Delta N I_{i t}=\alpha_{0}+\alpha_{1} D+\beta_{0} \Delta N I_{i t-1}+\beta_{1} D \times \Delta N I_{i t-1}+\varepsilon_{i t} \\
\Delta N I_{t, i}=\frac{E P S_{t}-E_{S_{t}-1}}{P_{t}},
\end{array}
$$

$D$ is a dummy variable, when $\Delta N I$ it $-1<0, D=1$; when $\Delta N I i t-1>0, D=0$. As loss is less persistent than gain, and is more likely to reverse, that is, $\beta 1$ should be significantly negative.

Using the Basu (1997) model, Li and Lu (2003) empirically analyzed accounting conservatism of Chinese listed companies, and found that bad news reflected in the accounting earnings is more quickly reflected than good news. The accounting earnings changes are also asymmetric; negative earnings changes reverse greater than the positive earnings changes (weaker persistent). Therefore, they maintain that Chinese listed companies' accounting earnings are conservative in general. However, $\mathrm{Li}$ and Li (2005) point out that the conservatism is not caused by real prudence. Xiao and Lv (2009) believe that financial reports of Chinese listed companies are conservative, and earnings manipulation is not the source of earnings conservatism when they used the basis of 
quarterly earnings data. Mao (2009) analyzed the relationship of earnings conservatism and earnings management, and summarized the earnings conservatism of Chinese listed companies is linking closely to the principle of conservatism of the accounting system.

\subsection{Relationship model of the disposition effect and conservatism}

Grinblatt and Han (2005) find that in the prediction of future stock return, investor's capital gains are more predictive than past stock returns. After adding capital gain into model (7), the significances of $a 1, a 2, a 3$ are lower than before.

$$
r 4=a 0+a 1 r 1+a 2 r 2+a 3 r 3+a 4 V+a 5 s+a 6 g+\varepsilon(7)
$$

However, different results may appear in different markets. Using Chinese capital market data in the study, the article focuses on conservatism's effect on the disposition effect. From this perspective, we will mainly test the coefficient $a 10$ of the cross-term $g * D$ and the coefficient $a 12$ of $g * D 0$, and predict $a 8$ is significantly positive, and $a 10$ and $a 12$ are significantly negative.

$$
\begin{aligned}
& r_{4}=a_{0}+a_{1} r_{1}+a_{2} r_{2}+a_{3} r_{3}+a_{4} V_{1}+a_{5} V_{2}+a_{6} V_{3}+a_{75} \\
& +a_{8} g+a_{9} D+a_{10}{ }^{*} D+a_{11} D_{0}+a_{12} g^{*} D_{0}+\varepsilon
\end{aligned}
$$

In general, there is no momentum in Chinese capital market in the stock return test alone, after adding volume into the test, the stock portfolio of low trading volume exists momentum, and the stock portfolio of high trading volume reversed significantly( $\mathrm{Zhu}, \mathrm{Wu}$ and Wang, 2004), following, we control the various horizons' volume in this study. $\mathrm{s}$ refers to the natural logarithm of market capitalization; $g$ refers to investors' capital gain; $D=0$ refers to companies gain; $D=1$ refers to companies loss; $D 0=0$ refers to companies earnings being greater than in the preceding quarter; $D 0=1$ refers to companies earnings are greater than in the preceding quarter.

\section{The Relationship of Accounting Conservatism and the Disposition Effect}

\subsection{Data and sample choice}

In the choice of cross section samples, we must consider the following factors:

1) As low-frequency time-series observations will lead to weak statistical evidence, we should maximize the cross-section sample of the time series of observations as far as possible, so there is little or no doubt that using quarterly data offers the best available observations. However, Chinese listed companies only began to provide quarterly financial report data after 2002, therefore when selecting samples we must choose the samples from those that were continuously listed from 2002 to 2009;

2) After finding the samples that satisfy the time series requested, the next step that is required, is to find samples that have the requested data for each year, including turnover, closing price, quarterly earnings, and rate of return. All the data has been obtained from the CCER and CSMAR database.

In total 531 companies have been selected because they meet the requirements that have been identified as necessary to be included as samples in the study. The industry distribution of the samples is shown as below in Figure 1. It can be seen that the oil, plastic, metal, machinery, biology and retail industries are strongly represented, while communication, agriculture, wood and paper are less represented.

\subsection{Descriptive statistical analysis}

In figure 2, capital gains are steadily diminishing. We can see investor's capital gains are greater than 0 during 2002 to 2006, while capital gains fluctuated around 0 during the period from 2007 to 2009. This implies that investors were able to get excess returns in the early Chinese stock market, while investors were not able to obtain excess returns in recent years, and the returns tend to fluctuate around 0. From figure 2, we can also find there are significant turning points in December 2007, March 2008 and September 2008, which are consistent with the share-list at that time. After the stock market reached a peak of more than 6,000 points in October 2007 an immediate and drastic shrinkage of investors' assets emerged, and capital gains fell; in the first half of 2008, investors' capital gains increased slightly, however after the United States subprime crisis broke out, as the global economic crisis spread, we also find that Chinese stock market's investors' capital gains decreased significantly. Nevertheless, capital gains still fluctuated around 0 , indicating investors could not obtain long-term excess returns.

\subsection{Test of factors deciding capital gains}

In the discussion above, since the method used for calculating the reference point in the formula (1) is based on 
past stock prices and turnovers, in the model (4), we revert or 'regress' capital gain to be in line with past stock prices and turnovers, at the same time controlling the impact of firm size. So we obtain model (9) by adding $r 4$; Table 2 is the model (9)'s regression results.

$$
g=a 0+a 1 r 1+a 2 r 2+a 3 r 3+a 4 r 4+a 5 V 1+a 6 V 2+a 7 V 3+a 8 s+\varepsilon
$$

Table 1 Line 3 is the result of not adding $r 4$, capital gain is only regressed on past returns and turnovers. We found the coefficients of $r 1, r 3, V 1, V 2, V 3$ are significantly negative; the results are the same with the predictive signs except for $r 2^{\text {'s }} \mathrm{s}$ coefficient. When adding $r 4$, the regression results are shown in Table 1, line 4, we note the coefficient of $r 4$ is significantly positive, indicating that $r 4$ has a positive interpretation relative to capital gains, while $r 1, r 2, r 3, V 1, V 2, V 3$ has a negative explanatory power.

\subsection{Test of relationship between accounting conservatism and the disposition effect}

We find that the capital gain is the underlying cause of medium momentum effect, however when applying it in the Chinese stock market; we get the results as shown in Table 2. As in the model (8), $r 1$ is the cumulative return that occurred in one month; $r 2$ is the cumulative return that occurred from one month to one year; $r 3$ is the cumulative return that occurred from one year to three years. Accordingly, $V 1, V 2, V 3$ are the corresponding periods' turnovers; $\mathrm{s}$ is the natural logarithm of market capitalization measured at the beginning of week t; $g$ refers to investors' capital gain; $D=0$ refers to companies gain; $D=1$ refers to companies loss; $D 0=0$ refers to companies earnings that are greater than the preceding quarter; $D 0=1$ refers to companies earnings that are lower than preceding quarter.

$$
\begin{aligned}
& r_{4}=a_{0}+a_{11} r_{1}+a_{2} r_{2}+a_{3} r_{3}+a_{4} V_{1}+a_{5} V_{2}+a_{6} V_{3}+a_{75} \\
& +a_{8} g+a_{9} D+a_{10}{ }^{*} D+a_{11} D_{0}+a_{12} g^{*} D_{0}+\varepsilon
\end{aligned}
$$

Table 2, Column 2 includes the prediction symbols based on the foregoing reasoning; column 3 is the result of test of prices momentum in the Chinese stock market. Slightly different to Jegadeesh and Titman(1993), there was exiting price momentum in the Chinese stock market, and the coefficients of $a 1, a 2, a 3$ are significantly greater than 0 . This momentum effect exits not only in the medium term, but also in the short term and long term.

Table 2, column 4 includes regression results after adding capital gain $g$. This study differs from the Grinblatt and Han (2005) study, in that our findings show, after adding capital gain $g$, the original price momentum effect was not affected and $g$ is the reason explaining the future return as well as short, medium and long term returns.

Based on the tests above, the accounting conservatism variables $D$ and $D 0$ are added to the model separately. Table 2 column 5 and 6 are the test results, where the regression coefficients of $g * D-a 10$ and the coefficients of $g * D 0-a 12$ are significantly negative, while the two regressions' coefficients $a 8$ are significantly positive. It shows that there is a counteractive power of the conditional accounting conservatism when investors' capital gains affect the stock price. These results are consistent with the previous theoretical analysis. In the last column of Table 2, adding the two conservatism indicators into the model, we still find the coefficients of cross-items $a 10$ and $a 12$ are significantly negative, however $a 8$ is significantly positive. This is consistent with the previous analysis. Whether investors show either a gain or a loss, accounting conservatism will have a modified role on such price volatility that arises due to the disposition effect. In addition, the observed capital gains coefficient $a 8$ become greater as the conservatism variables are added, which suggests $g$ has already contained the conservatism's modified role while at the same time has not added conservatism variables. When controlling the conservatism, the role of capital gain on price return may expose clearly, and this supplies the further evidence that conservatism's governance role on the disposition effect.

\section{Conclusion}

The research combines accounting conservatism with capital markets' irrational behavior, e.g., the Disposition Effect, and focuses on the governance role of conservatism on the disposition effect. We show the statistical description of the proxy variable of capital gain, finding Chinese investors were able to obtain the excess returns during the early period, while capital gains fluctuated around 0 during 2007 to 2009. This information indicates that the Chinese stock market is more effective in recent years than in previous years. In the tests of factors deciding capital gain, we find $r 4$ has a positive interpretation to capital gains, however $r 1, r 2, r 3, V 1, V 2, V 3$ has a significantly negative explanatory power. As investors' irrational investment behavior results in overestimation or underestimation, we discover conservatism adversely affects irrational pricing behavior, and then modifies the market's mispricing. That is investors hold nominal losses preferring not to realize loser but 
sell winners to realize nominal gains. Over time as shown in Figure 2 gains will diminish as winners are sold early and investors have fewer winners to sell.

From the perspective of irrational pricing behavior, this research provide important information for investors, academic professionals and policy makers that accounting information plays a significant role in financial decision making. The research finding will also help governance mechanism to remedy "inaccurate" market pricing in the correction of the pro-cyclical behavior of financial markets and financial institutions.

\section{References}

Barberis, N., Huang, M., and Santos, T. (2001). Prospect Theory and Asset Prices. Quarterly Journal of Economics, Vol.116 (1).1-53.

Basu. S. (1997). The Conservatism Principle and the Asymmetric Timeliness of Earnings. Journal of Accounting and Economics, Vol.24 (1): 3-37. http://dx.doi.org/10.1016/S0165-4101(97)00014-1

Chen, G., Kim, K.., Nofsinger, J., and Rui, O. (2007). Trading Performance, Disposition Effect, Overconfidence, Representativeness Bias, and Experience of Emerging Market Investors, Working Paper, State University of New York at Buffalo.

Gao, L., He. S., and Su, C. (2005). The disposition effect and self-valuation. Economic Theory and Economic Management, Vol. (9).

Genesove, D., and Mayer, C. (2001). Loss aversion and seller behavior: Evidence from the housing market. Quarterly Journal of Economics, Vol. 116, 1233-1260. http://dx.doi.org/10.1162/003355301753265561

Grinblatt, M., and Han, B. (2005). Prospect theory, mental accounting and momentum. Journal of Financial Economics, Vol., 78, 311-339. http://dx.doi.org/10.1016/j.jfineco.2004.10.006

Heath, C., Huddart, S., and Lang, M. (1999). Psychological factors and stock option exercise. Quarterly Journal of Economics, Vol.114, 601-627. http://dx.doi.org/10.1162/003355399556089

Hyuk,C., and Yunsung, E. (2009). The Disposition Effect and Investment Performance in the Futures Market. The Journal of Futures Markets, Vol. 29(6), 496-522. http://dx.doi.org/10.1002/fut.20398

Jegadeesh, N., and Titman, S. (1993).Returns to buying winners and selling losers: Implications for stock market efficiency. Journal of Finance, Vol. 48, 65-91. http://dx.doi.org/10.2307/2328882

Kahneman, D., \& Tversky, A. (1979). Prospect theory: an analysis of decision under risk. Econometrica, Vol. 47,263-291. http://dx.doi.org/10.2307/1914185

Kaustia, M. (2004). Market-wide impact of the disposition effect: evidence from IPO trading volume. Journal of Financial Markets, Vol. (7), 207-235.

Li, P., and Li, R. (2005). Is it the conservatism of earnings, or profit manipulation? - From Chinese Listed Companies in China. Accounting and Financial Studies, Vol.7 (3): 1-31.

Li, X., and Zhang, W. (2005). Institutional Investors "disposition effect" of empirical research. Modern Economic Science, Vol. (9):76-80.

Li, Z., and Lu, W. (2003). Conservatism of accounting earnings: discovery and enlightenment. Accounting Research Journal, Vol.2: 19 -27.

Lu, L., and Li, X. (2002). The disposition effect of Chinese stock market investors. Shenzhen Stock Exchange Research Institute report, 2002.

Mao, X. (2009). Accounting system reform, Conservatism and Earnings Management. 2009 National Seminar on Accounting, China.

Odean, T. (1998). Are Investors reluctant to realize their losses? Journal of Finance, LIII, 1775-1798. http://dx.doi.org/10.1111/0022-1082.00072

Shefrin, H., and Statman, M. (1985). The Disposition to Sell Winners Too Early and Ride Losers Too Long: Theory and Evidence. Journal of Finance, Vol.40, 779-790. http://dx.doi.org/10.2307/2327802

Sun, J., Chen, G., and Wang, M. (2007). The empirical research of Disposition effect in securities trading. Psychological Science, Vol. 30 (3):731-734.

Sun, P., and Shi, D. (2002). Are investors always risk-averse? - Evidence from China stock market. Stock Market Review, 2002, (9):54-57

Szyszka, A., and Zielonka, P. (2007). The Disposition Effect Demonstrated on: IPO Trading Volume, Working 
Paper, 2007, Poznan University of Economics

Thaler, R. (1980). Toward a positive theory of consumer choice. Journal of Economic Behavior and Organization, Vol.1, 39-60. http://dx.doi.org/10.1016/0167-2681(80)90051-7

Wang, J. (2007). The empirical study on the open-end fund investment style deviation effects on dispose effect. The World Economy, Vol. (11).

Xiao, C., and Lv, C. (2009). Is it the conservatism of earnings, or profit-fixing? - The empirical evidence based on quarter earnings. 2009 National Seminar on Accounting, China.

Zhao, X., and Wang, Y. (2001). The empirical analysis of Chinese stock market's disposition effect. Financial Research, Vol. (7): 92- 97. [Online] Available: http://www.csscipaper.com/eco/investment/46011.html

Zhu, Z., and Wu, C. (2004). Price Momentum and Trading Volume: An Empirical Study of the Comparison of China and International. Systems Engineering Theory \& Practice, Vol. (2).

Table 1. The Regression Results of Model (9)

\begin{tabular}{|c|c|c|c|c|c|}
\hline 1 & & $a_{1}$ & $a_{2}$ & $a_{3}$ & $a_{4}$ \\
\hline 2 & $\begin{array}{c}\text { Predictive } \\
\text { sign }\end{array}$ & - & - & - & ? \\
\hline 3 & & $\begin{array}{c}-0.0442^{* * *} \\
(-5.1041)\end{array}$ & $\begin{array}{l}-0.0003 \\
(-1.287)\end{array}$ & $\begin{array}{c}-0.0013 * * * \\
(-22.4571)\end{array}$ & $\bar{\square}$ \\
\hline 4 & & $\begin{array}{c}-0.0485^{* * *} \\
(-5.5822) \\
\end{array}$ & $\begin{array}{c}-0.0007^{* * * *} \\
(-2.6735)\end{array}$ & $\begin{array}{c}-0.0013^{* * * *} \\
(-22.4422) \\
\end{array}$ & $\begin{array}{c}0.0046^{* * *} \\
(5.1251)\end{array}$ \\
\hline 1 & & $a_{5}$ & $a_{6}$ & $a_{7}$ & as \\
\hline 2 & $\begin{array}{l}\text { Predictive } \\
\text { sign }\end{array}$ & - & - & - & ? \\
\hline 3 & & $\begin{array}{c}-0.0588 * * * \\
(-12.6544) \\
\end{array}$ & $\begin{array}{c}-0.0507^{* * *} \\
(-82.1615) \\
\end{array}$ & $\begin{array}{c}-0.0075^{* * *} \\
(-19.5755) \\
\end{array}$ & $\begin{array}{r}0.0229^{* * * *} \\
(174.161)\end{array}$ \\
\hline 4 & & $\begin{array}{l}-0.0589 * * * \\
(-12.6881)\end{array}$ & $\begin{array}{c}-0.0507^{* * *} \\
(-82.3168)\end{array}$ & $\begin{array}{c}-0.0074^{* * *} \\
(-19.2669)\end{array}$ & $\begin{array}{l}0.0229^{* * *} \\
(174.127)\end{array}$ \\
\hline
\end{tabular}

Notes: *** $1 \%$ level significance, $* * 5 \%$ level significance, $* 10 \%$ level significance

Table 2. Regression Results

\begin{tabular}{|c|c|c|c|c|c|c|}
\hline 1 & 2 & 3 & 4 & 5 & 6 & 7 \\
\hline$a_{1}$ & $?$ & $\begin{array}{c}1.1741^{* * * *} \\
(116.77)\end{array}$ & $\begin{array}{c}1.6156^{* * * *} \\
(280.29)\end{array}$ & $\begin{array}{c}1.6146^{* * *} \\
(280.28)\end{array}$ & $\begin{array}{c}1.7969 * * * * \\
(268.51)\end{array}$ & $\begin{array}{c}1.9526 * * * * \\
(605.58)\end{array}$ \\
\hline$a_{2}$ & $?$ & $\begin{array}{c}0.2821^{* * * *} \\
(89.04)\end{array}$ & $\begin{array}{c}0.2717^{* * *} \\
(84.15)\end{array}$ & $\begin{array}{c}0.2729^{* * *} \\
(84.33)\end{array}$ & $\begin{array}{c}0.0140^{* * * *} \\
(15.00)\end{array}$ & $\begin{array}{c}0.0100^{* * * *} \\
(12.78)\end{array}$ \\
\hline$a_{3}$ & $?$ & $\begin{array}{c}0.0001^{*} \\
(1.73) \\
\end{array}$ & $\begin{array}{c}0.0004^{* * *} \\
(4.83)\end{array}$ & $\begin{array}{c}0.0004^{* * *} \\
(4.89)\end{array}$ & $\begin{array}{c}-0.00006 \\
(-0.67)\end{array}$ & $\begin{array}{l}0.0000 \\
(0.06)\end{array}$ \\
\hline$a_{4}$ & $?$ & $\begin{array}{c}0.2294^{* * * *} \\
(42.90)\end{array}$ & $\begin{array}{c}0.1886^{* * * *} \\
(32.74) \\
\end{array}$ & $\begin{array}{c}0.1874^{* * * *} \\
(32.54)\end{array}$ & $\begin{array}{c}0.2283^{* * * *} \\
(33.90) \\
\end{array}$ & $\begin{array}{c}0.1947 * * * \\
(26.71) \\
\end{array}$ \\
\hline$a_{5}$ & ? & $\begin{array}{c}-0.0276^{* * * *} \\
(35.94)\end{array}$ & $\begin{array}{c}-0.0167^{* * *} \\
(-18.32)\end{array}$ & $\begin{array}{c}-0.0165^{* * *} \\
(-18.04)\end{array}$ & $\begin{array}{c}0.0030^{* * * *} \\
(2.91)\end{array}$ & $\begin{array}{c}0.0062^{* * *} \\
(5.49)\end{array}$ \\
\hline$a_{6}$ & $?$ & $\begin{array}{c}0.0044^{* * *} \\
(12.09)\end{array}$ & $\begin{array}{c}0.0056^{* * *} \\
(14.25)\end{array}$ & $\begin{array}{c}0.0054^{* * *} \\
(13.75)\end{array}$ & $\begin{array}{c}-0.0047 * * * \\
(-10.52)\end{array}$ & $\begin{array}{c}-0.0043^{* * *} \\
(-8.51)\end{array}$ \\
\hline$a_{7}$ & $?$ & $\begin{array}{c}-0.0003^{* *} \\
(-2.03)\end{array}$ & $\begin{array}{c}-0.0026^{* * * *} \\
(-10.60)\end{array}$ & $\begin{array}{c}-0.0029 * * * \\
(-11.47)\end{array}$ & $\begin{array}{c}0.0908^{* * * *} \\
(18.47)\end{array}$ & $\begin{array}{c}0.0919^{* * *} \\
(17.19)\end{array}$ \\
\hline as & + & & $\begin{array}{c}0.1080^{* * *} \\
(13.68)\end{array}$ & $\begin{array}{c}0.1251^{* * *} \\
(14.55)\end{array}$ & $\begin{array}{c}0.1488^{* * *} \\
(13.96)\end{array}$ & $\begin{array}{c}0.1649 * * * \\
(13.95)\end{array}$ \\
\hline$a_{9}$ & ? & & & $\begin{array}{c}0.0469^{* * * *} \\
(6.98)\end{array}$ & & $\begin{array}{l}-0.0008 \\
(-0.09)\end{array}$ \\
\hline$a_{10}$ & - & & & $\begin{array}{c}-0.0925^{* * *} \\
(-5.85) \\
\end{array}$ & & $\begin{array}{c}-0.0831^{* * *} \\
(-4.39)\end{array}$ \\
\hline$a_{11}$ & ? & & & & $\begin{array}{c}0.0999 * * * \\
(17.59)\end{array}$ & $\begin{array}{c}0.0909 * * * \\
(14.07)\end{array}$ \\
\hline$a_{12}$ & - & & & & $\begin{array}{c}-0.0471^{* * * *} \\
(-3.38)\end{array}$ & $\begin{array}{c}-0.0379^{* * *} \\
(-2.55)\end{array}$ \\
\hline
\end{tabular}

Notes: $* * * 1 \%$ level significance, ${ }^{* *} 5 \%$ level significance, $* 10 \%$ level significance 


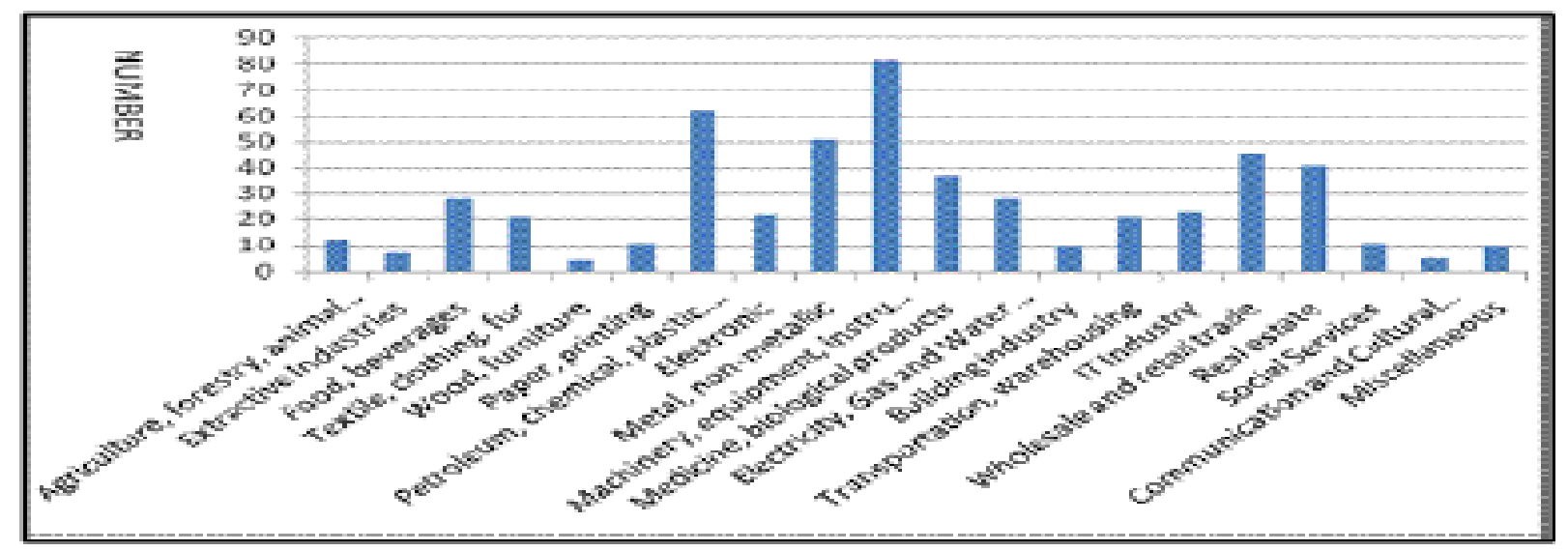

Figure 1. 531 Samples showing industry distribution

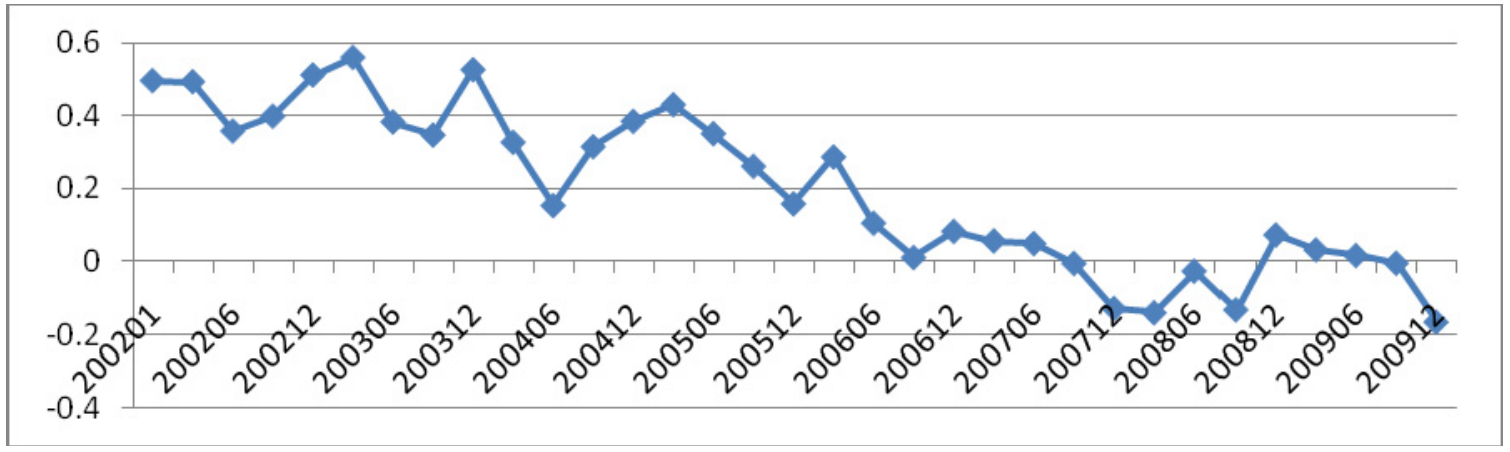

Figure 2. Capital gain graph from 2001 to 2009 